\title{
THE LINK OF DIET AND EXERCISE HABITS OF THE INHABITANTS OF PÄRNU CITY WITH BODY MASS INDEX
}

\author{
Kandela Õun, Monika Übner \\ Pärnu College, University of Tartu, Pärnu, Estonia
}

\begin{abstract}
This article gives an overview of the health behaviour survey of the adult population of the city of Pärnu, which was conducted in 2016. The results of the survey were used for compiling of the city health profile. The funder was the Pärnu city government. The authors focused on the links between the body mass index, diet and physical activity. The survey was carried out among the residents of the city of Pärnu aged 16-64 years. The questionnaire was filled by 506 respondents. Such a large survey had not been carried out in the city of Pärnu previously. In 2011 and 2014 two studies involving whole Estonia were conducted, in which the percentage of the respondents from Pärnu was too small to make further conclusions.

The study results revealed that $65 \%$ of respondents ranked their health good or very good, and that was an improvement compared to the previous survey made five years ago. Breakfast was important for respondents, and $86 \%$ of them had it every morning or on most days. $49 \%$ of respondents were of normal weight by body mass index and $47 \%$ were overweight or obese, and these numbers showed a $20 \%$ change for better health compared to the previous study. From April to September, $45 \%$ of respondents rode a bicycle to work. In their free time, $60 \%$ did it for at least 15 minutes per day. Women walked to the workplace more often than men. Men were more overweight and ate more white bread than women. Underweight respondents ate an average of one slice of white bread per day, while others consumed it twice less on average. There was a significant but small correlation between age and BMI ( $r=0.31)$, respondents with vocational education had the highest average BMI. Obese persons and respondents with poor physical fitness were less active than normal-weight persons.
\end{abstract}

Keywords: body mass; diet; exercise habits 


\section{INTRODUCTION}

The main guidelines for weight control recommend, among others, avoiding or moderating skipping of breakfast, eating at fast-food restaurants, snacking, and eating while watching television [2]. Muñoz-Pareja et al. [2, p. 6] have found that, as regards consumption of beverages, not planning the amount of food to eat, eating at fast-food restaurants and eating while watching TV were associated with higher intake of sugary drinks. Moreover, those who rarely chose low energy food had a higher consumption of alcoholic beverages.

Current American Heart Association (AHA) diet and lifestyle recommendations [4] emphasize among others engagement in regular physical activity and consumption of diets rich in vegetables and fruits, whole grains, low-fat and non-fat dairy products, legumes, fish (at least twice a week), and lean meat, coupled with food choices that minimize intakes of excess energy, saturated fat, trans fat, cholesterol, and salt. Oda-Montecinos et al. [6] has shown direct significant correlations between BMI and age. According to their study, men were more overweight than women. For women, the number of children was directly and significantly correlated with BMI. Adult eating behaviours are related to overweight and obesity. Parents also create children's behaviour in eating patterns. Higher educational level and low BMI value are related. Therefore, the education level may protect the person against obesity. Muñoz-Pareja et al. [5] found that obesity is associated with higher amount of dairy products, especially cheese, red meat, sugar-sweetened soft drinks and beer. Subjects whose BMI was higher consumed less fresh fruit, fish and white meat.

In the research of Finnish and German respondents by Pentikäinen et al. [7], food products were divided into seven groups based on their healthiness: super and functional food, unhealthy snacks and convenience foods, healthy foods, sweets, alcoholic beverages, low-fat dairy products, and fresh meat and fish. In the Australian research "Obesity and healthy eating in Australia" [13] five core food groups were distinguished: grains and cereals, vegetables, fruit, dairy products (and alternatives), lean meats and alternatives.

The food pyramid groups compiled by the Estonian Institute for Health Development (EIHD) [8] include: 1) cereal products and potatoes, 2) fruit and vegetables, berries, 3) milk and dairy products, 4) fish, poultry, meat, eggs, 5) sugar and sweets, sweet and salty snacks, 6) mixed foods, 7) alcohol-free drinks, 8) food supplements.

BMI is also connected with physical activity. The Estonian National Physical Activity Survey [9] concluded that only $22 \%$ of the Estonian population was 
sufficiently physically active and $20 \%$ were obese. Physical activity is agerelated - younger persons are more active. Overweight and normal weight men were equally active, which is explained by larger muscle mass in the overweight male group. Increasing physical activity and making changes in persons' dietary habits lowerd the BMI [3].

The aim of this study was to find the link between the body mass index and eating habits and physical activity.

\section{MATERIAL AND METHODS}

The survey was conducted on the basis of the Pärnu County report [14] and a survey of the Estonian adult population's health behaviour conducted in 2014 [10]. The research areas were related to the indicators of healthy lifestyle indicated in the guidelines for the preparation of the local and regional health profiles [12, p. 39]. The survey was conducted on the web in LimeSurvey (http://survey.ut.ee) and on paper in both Estonian and Russian. The survey respondents were gathered with the snowball method by sharing the webbased questionnaire from respondents to their friends, and paper questionnaires were filled with the help of students with convenience sampling. The questionnaire contained 52 questions. The survey was conducted between 1 November 2016 and 15 December 2016. The data were processed using the SPSS 23.0 statistical program.

According to the data of the Statistical Office of Estonia, on 1 January 2016, the population of Pärnu aged 16-64 was 23,963, of which 11,331 (47\%) were men and $12,632(53 \%)$ were women. The representability of the collected database is good. The territory of the city of Pärnu is 33.15 square kilometres, and there are seven different residential districts. The number of respondents from different districts is proportionally distributed compared with the data of the city government about their inhabitants in 2016. The distribution of age is similar to the distribution of the inhabitants of Pärnu city, although the number of residents aged 16-25 and 56-64 is slightly lower in the survey, and the number of respondents aged 26-35 slightly higher than in Pärnu city as a whole. In terms of ethnicity, Russians were less likely to be surveyed than in Pärnu in general (15\% in 2014), so the results for ethnicity cannot be provided in this study. The balance between women and men is in favour of women ( $48 \%$ of men and 52\% of women lived in Pärnu on 1 January 2016), but there were enough men among respondents to provide indicators for them. 
The mean age of the participants was 40.4 years $(\mathrm{SD}=12.8,16-64)$ with 388 women $(76.9 \%, \mathrm{M}$ age $=41.3, \mathrm{SD}=12.6)$ and 117 men $(23.1 \%, \mathrm{M}$ age $=37.4$, $\mathrm{SD}=12.9)$. Regarding marital situation, $67 \%(\mathrm{n}=339)$ were married or had a partner, $20 \%$ were single $(n=103)$ and $12.7 \%(n=64)$ were divorced or widowed. Regarding educational status, there were $54 \%$ of respondents with higher $(n=173)$ and $44 \%$ with secondary or vocational education. One-third of the respondents lived in a two-member household, $42.3 \%$ had three or four members in their household, and $15.2 \%$ lived alone. $56 \%$ of respondents lived in a household where there were no children, only a quarter had children from 7 to 17 years of age; $11 \%$ of respondents had children up to 7 years of age. $82 \%$ of respondents were working, and $69.8 \%$ worked full-time. There were $11 \%$ of entrepreneurs or freelancers among the respondents. The main areas of activity were service or office work $(40 \%, n=202)$, culture or education $(32 \%, n=160)$ and construction, transportation or industrial work $(11 \%, \mathrm{n}=55)$.

The body mass index (BMI) was calculated using the following standard equation: BMI $\left(\mathrm{kg} / \mathrm{m}^{2}\right)=$ weight $(\mathrm{kg}) /$ height $(\mathrm{m})^{2}$. According to the international classification of body weight [11], [15]we investigated the influence of personal body size, indexed by body mass index (BMI, obesity is defined as a BMI of 30 and above, overweight as a BMI between 25 and 29.9, normal weight as a BMI between 18.5 and 24.9, and underweight as a BMI below 18.5.

Food consumption frequency was estimated by asking respondents to rate their consumption frequency of 26 food products (including dairy products, meat products, functional foods, convenience foods, snacks, vegetables, fruits and berries, beverages, cereal products, pasta and rice, and superfoods) on a 4-point scale in which 1 - never, 2 - on 1 or 2 days per week, 3 - on 3-5 days, 4 - on 6-7 days per week. The food products were united to the factors by calculating their average consumption value.

Cross-tabulation with chi-square and pairwise comparisons with the t-test were performed to compare the gender, age and education groups. One-way analysis of variance (ANOVA) with Tukey's HSD (honest significant difference) test for comparisons was used to compare the segments' food consumption and BMI classes.

\section{RESULTS AND DISCUSSION}

First, some findings can be compared with literature. By Oda-Montecinos et al. [6], men were more overweight than women, and it was also so in the Pärnu database by BMI $\left(\mathrm{M}_{\text {men }}=26.36, \mathrm{SD}=4.1, \mathrm{M}_{\text {women }}=25.31, \mathrm{SD}=5.2, \mathrm{t}=-2.81\right.$, $\mathrm{p}=0.023)$. The distribution of BMI by gender is shown in Table 1 . 
Table 1. Distribution of body mass index by gender

\begin{tabular}{lllccccc}
\hline & & \multicolumn{4}{c}{ BMI classification } & \\
\cline { 3 - 7 } & & $\begin{array}{c}\text { Under- } \\
\text { weight }\end{array}$ & $\begin{array}{c}\text { Normal } \\
\text { weight }\end{array}$ & $\begin{array}{c}\text { Over- } \\
\text { weight }\end{array}$ & Obese & Total \\
\hline \multirow{2}{*}{ Female } & Count & 10 & 203 & 103 & 60 & 376 \\
\cline { 2 - 7 } & $\%$ within BMI class & $2.7 \%$ & $54 \%$ & $27.4 \%$ & $16 \%$ & $100 \%$ \\
\hline \multirow{2}{*}{ Male } & Count & 1 & 47 & 50 & 18 & 116 \\
\cline { 2 - 7 } & \% within BMI class & $0.9 \%$ & $40.5 \%$ & $43.1 \%$ & $15.5 \%$ & $100 \%$ \\
\hline \multirow{2}{*}{ Total } & Count & 11 & 250 & 153 & 78 & 492 \\
\cline { 2 - 6 } & \% within BMI class & $2.2 \%$ & $50.8 \%$ & $31.1 \%$ & $15.9 \%$ & $100 \%$ \\
\hline
\end{tabular}

There was also a significant but small correlation between age and BMI $\left(\mathrm{r}=0.31, \mathrm{r}_{\mathrm{men}}=0.401, \mathrm{r}_{\text {women }}=0.31\right)$ in our database, but no correlation for women between the number of children and BMI, as Oda-Montecinos et al. [6] reported.

Oda-Montecinos et al. [6] also found that higher educational level and low BMI value were related. In our database, respondents with vocational education had the highest average $\mathrm{BMI}(\mathrm{M}=26.8, \mathrm{SD}=5.5)$, respondents with basic or secondary education had average BMI 24.1-24.8 and with higher education 25.5. According to our data, obesity was not associated with higher consumption of dairy products, meat, sugar-sweetened soft drinks and beer. Subjects whose BMI was higher did not consume less fresh fruit, fish and meat.

Breakfast is considered to be the most important meal of the day, and $67 \%$ of the respondents eat it daily, and $19 \%$ of respondents eat breakfast mostly. Although there were fewer men than women in the dataset, there were no major differences in breakfast eating rates. $69 \%$ of women and $60 \%$ of men eat breakfast daily. There were, however, some differences by age. Namely, $80 \%$ of 46-64-year-old women eat breakfast every morning, while among younger women the percentage is $61-64 \%$. Among men, breakfast is most commonly eaten by $36-45$-year-old men (73\%) and the least (48\%) by $26-35$-year-old men. Women with higher education are more likely to have breakfast every day than women with lower education. In the case of men, this trend could not be identified.

In the study of dietary habits, respondents were asked about the consumption of different products and the following results were obtained: there was a statistically significant difference between men and women in eating white 
bread $\left(\mathrm{M}_{\text {woman }}=0.44\right.$ slices per day, $\mathrm{SD}=0.96, \mathrm{M}_{\mathrm{men}}=0.94, \mathrm{SD}=1.7, \mathrm{t}=-2.94$, $\mathrm{p}=0.004)$. Rye bread was consumed on an average 1.5 , fine rye bread 0.4 and a graham bread 0.8 slices per day, and water on an average 0.9 litres per day. During the day, men drink coffee a little more than women $\left(\mathrm{M}_{\text {woman }}=2.3\right.$ small cups per day, $\mathrm{SD}=1.7, \mathrm{M}_{\text {men }}=2.5, \mathrm{SD}=2.0, \mathrm{t}=-0.96, \mathrm{p}=0.338$ ).

In different classes of BMI, there was a statistically significant difference in eating of white bread; it showed that underweight respondents ate one slice of white bread per day on average ( $\mathrm{SD}=1.3, \mathrm{n}=11$ ), while others consumed it twice less on average $(\mathrm{M}=0.48-0.68, \mathrm{SD}=1.0-1.5) .11 \%$ of men and women do not use sweeteners, $41.5 \%$ of women use refined (white) sugar, as well as $51.3 \%$ of men, and $51 \%$ of obese, while $39 \%$ of normal and overweight women use it.

Honey was consumed by $20-30 \%$ of the respondents, and more likely they were women of normal weight. $39 \%$ of women and $32 \%$ of men never add extra salt to their food, but $13 \%$ of men and $7 \%$ of women add extra salt before tasting of food, and this is more often done by $17 \%$ of men of normal weight. Of various salts, the respondents mostly use the fine salt (36\% of women, $51 \%$ of men, $40 \%$ of women of normal weight, $33 \%$ of obese men) and sea salt (30\% of women, $26 \%$ of men, $25 \%$ of women of normal weight); $24 \%$ of women and $12 \%$ of men use rock salt.

The current survey also analysed the respondents' physical activity. $82 \%$ of men and $80 \%$ of women considered their physical fitness to be satisfactory or quite good, while $50 \%$ of obese and overweight respondents were also satisfied with their physical fitness. There were also statistically significant differences between the different BMI classes, so it can be said that obese persons (women Chi-square $=25.4, \mathrm{p}=0.003$, men Chi-square $=29.6, \mathrm{p}=0.000)$ and respondents with poor physical fitness (women Chi-square $=75.3, p=0.000$, men Chi-square $=18.4, \mathrm{p}=0.019$ ) are less active than persons of normal weight.

$33 \%$ of the respondents do active exercises which cause deeper breathing and some sweating for at least 30 minutes (see Table 2 by BMI classes), and there was a statistically significant difference between BMI classes (men Chisquare $=29.9, \mathrm{p}=0.000$, women Chi-square $=25.4, \mathrm{p}=0.003$ ). In an earlier study [9] only $22 \%$ of respondents were more physically active. $41 \%$ of all men are active in some sports several times a week, and the same indicator in obese men is $22 \%$, in all women $28 \%$, and in obese women $18 \%$. No active exercise is done at all by $21 \%$ of men and $35 \%$ of women, as well as by $50 \%$ of obese men and $60 \%$ of obese women. 
Table 2. Frequency of active exercise by BMI classes

\begin{tabular}{|c|c|c|c|c|c|c|c|c|c|}
\hline \multirow{2}{*}{$\begin{array}{l}\text { Count } \\
\text { and \% } \\
\text { within } \\
\text { BMl } \\
\text { classes }\end{array}$} & \multicolumn{4}{|c|}{ Men } & \multicolumn{5}{|c|}{ Women } \\
\hline & $\begin{array}{l}\text { Normal } \\
\text { weight }\end{array}$ & $\begin{array}{l}\text { Over- } \\
\text { weight }\end{array}$ & Obese & Total & $\begin{array}{l}\text { Under- } \\
\text { weight }\end{array}$ & $\begin{array}{l}\text { Normal } \\
\text { weight }\end{array}$ & $\begin{array}{c}\text { Over- } \\
\text { weight }\end{array}$ & Obese & Total \\
\hline \multirow{2}{*}{$\begin{array}{l}\text { Not } \\
\text { at all }\end{array}$} & 8 & 7 & 9 & 24 & 2 & 62 & 33 & 36 & 133 \\
\hline & $17.0 \%$ & $14.0 \%$ & $50.0 \%$ & $20.9 \%$ & $20.0 \%$ & $30.5 \%$ & $32.0 \%$ & $60.0 \%$ & $35.4 \%$ \\
\hline \multirow{2}{*}{$\begin{array}{l}1-2 \\
\text { times } \\
\text { per } \\
\text { month }\end{array}$} & 3 & 16 & 4 & 23 & 2 & 27 & 21 & 6 & 56 \\
\hline & $6.4 \%$ & $32.0 \%$ & $22.2 \%$ & $20.0 \%$ & $20.0 \%$ & $13.3 \%$ & $20.4 \%$ & $10.0 \%$ & $14.9 \%$ \\
\hline \multirow{2}{*}{$\begin{array}{l}\text { Once a } \\
\text { week }\end{array}$} & 16 & 4 & 1 & 21 & 3 & 46 & 26 & 7 & 82 \\
\hline & $34.0 \%$ & $8.0 \%$ & $5.6 \%$ & $18.3 \%$ & $30.0 \%$ & $22.7 \%$ & $25.2 \%$ & $11.7 \%$ & $21.8 \%$ \\
\hline \multirow{2}{*}{$\begin{array}{l}\text { Several } \\
\text { times } \\
\text { per } \\
\text { week }\end{array}$} & 20 & 23 & 4 & 47 & 3 & 68 & 23 & 11 & 105 \\
\hline & $42.6 \%$ & $46.0 \%$ & $22.2 \%$ & $40.9 \%$ & $30.0 \%$ & $33.5 \%$ & $22.3 \%$ & $18.3 \%$ & $27.9 \%$ \\
\hline \multirow[t]{2}{*}{ Total } & 47 & 50 & 18 & 115 & 10 & 203 & 103 & 60 & 376 \\
\hline & $100.0 \%$ & $100.0 \%$ & $100.0 \%$ & $100.0 \%$ & $100.0 \%$ & $100.0 \%$ & $100.0 \%$ & $100.0 \%$ & $100.0 \%$ \\
\hline
\end{tabular}

One indicator of physical activity is also the frequency and purpose of walking or cycling, so the respondents were asked to say how many minutes they walked in one way or another to work or at leisure. Because of weather conditions, these modes have been divided into two periods, and it has been shown that $65 \%$ of respondents walk from April to September and $46 \%$ from October to March in their free time for at least 30 minutes per day. In their free time, $55 \%$ of respondents cycle from April to September, $17 \%$ of respondents from October to March, and they do it at least for 15 minutes per day. In Figure 1, men's and women's movement on foot or bicycles has been compared, and it is noticeable that women are more likely to walk and do this year-round, while men ride on bicycles more often in their free time from October to March. 
In free time

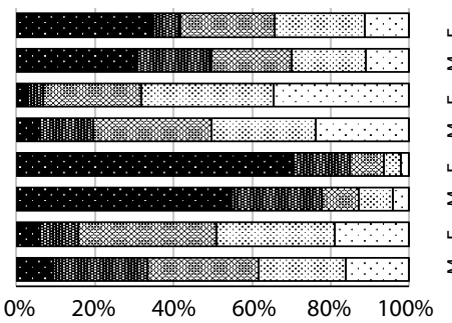

From home to work and back

$\begin{array}{lr}\sqcup & \text { from April to September on bicycle } \\ \Sigma & \\ \longleftarrow & \text { from April to September on foot } \\ \Sigma & \\ \longleftarrow & \text { from October to March on bicycle } \\ \Sigma & \\ \leftarrow & \text { from October to March on foot }\end{array}$
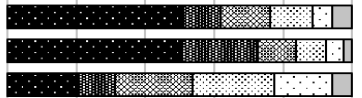

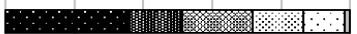

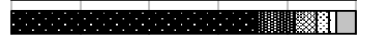

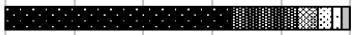

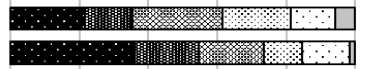

$\begin{array}{llllll}0 \% & 20 \% & 40 \% & 60 \% & 80 \% & 100 \%\end{array}$
- not at all

마 30-60 min per day itess than 15 min per day $15-30$ min per day $\square$ more than $60 \mathrm{~min}$ per day $\mathrm{a}$ I work at home

Figure 1. Physical activity in the leisure time. ( $\mathrm{M}$ - Male, F - Female)

In order to reduce the number of variables (from individual products to food product categories) and to categorize the listed foods in a way that reflected respondents' thinking and compare found factor structure with the EIHD food products pyramid [8], principal axis factor analysis (with varimax rotation) was performed. Principal axis factoring was chosen because the scales were not normally distributed [1]. The factor analysis used 29 food products and nine factors were extracted with eigenvalues above 1 , which explained $56.9 \%$ of the variance $(\mathrm{KMO}=0.74$, Bartlett's test of sphericity, $\mathrm{p}=0.00)$, so a statistically acceptable and meaningful solution was reached (see Table 3 ).

Table 3. The factor structure of food products

\begin{tabular}{lcl}
\hline Factor & $\begin{array}{c}\text { Cronbach } \\
\text { alpha }\end{array}$ & \multicolumn{1}{c}{ Food products } \\
\hline F1 & 0.387 & Rice, macaroni, fried potatoes, eggs \\
\hline F2 & 0.605 & $\begin{array}{l}\text { Vegetables (except potatoes) uncooked (in pieces, salad, etc.), fruits } \\
\text { and berries (other than juice) fresh and in foodstuffs, vegetables } \\
\text { (other than potatoes) in heat-treated form (i.e. cooked, stewed, etc.) }\end{array}$ \\
\hline F3 & 0.459 & Sour milk, kefir, yoghurt, curd milk cheese \\
\hline F4 & 0.32 & Poultry, meat products, fish, fishery products \\
\hline F5 & - & Confectionery (e.g. candy or chocolate) \\
\hline F6 & 0.558 & $\begin{array}{l}\text { Energy drinks, Coca-Cola or other sugar-containing, drinks, pizza, pies, } \\
\text { pastries, hamburger, food in can or jar (soup etc), prepared salads with } \\
\text { sour cream or mayonnaise sauce. }\end{array}$ \\
\hline F7 & 0.59 & $\begin{array}{l}\text { Cooked potatoes, meat and meat products (sausage, ham, wiener, } \\
\text { beefsteak, meatballs, etc.) }\end{array}$ \\
\hline F8 & 0.28 & Compotes, jams pudding, muesli, flakes \\
\hline F9 & - & Food supplements (e.g. vitamins, minerals) \\
\hline
\end{tabular}


The factors based on respondents' responses reflected the EIHD food pyramid [8] in a more or less similar way, but some eating habits that were typical for Estonians and difficult to terminate were revealed. Namely, Estonians tend to eat potatoes and meat or meat products (F7) cooked as one meal, as well as porridge and jam (F8), which led to the combination of these foods into common factors. Also, in factor F6, food groups 6 and 7 by EIHD [8] joined together as eggs moved into the same factor as rice, macaroni and fried potatoes. However, since the coherence of the factors developed was quite low (Cronbach alpha $<0.6$ ), the food items were aggregated according to the classification of the EIHD food pyramid groups [8] (also low coherence by Cronbach alpha, but still an official aggregation), and their mean consumption in different BMI groups was compared. There was no significant correlation between BMI and the factors found, also the BMI classes did not show statistically significant differences. The only factor that showed some significant differences (ANOVA, $\mathrm{F}=2.9 \mathrm{p}=0.034$ ) was $\mathrm{F} 2$ (vegetables and fresh berries, etc.), but the Tuckey HSD test did not show differences by pairs. By averages, it seems that obese respondents use vegetables and fresh berries less $(M=2.54$ in 4-point scale, $\mathrm{p}=0.059)$ than respondents of normal weight $(\mathrm{M}=2.76)$.

\section{CONCLUSION}

There were no statistically significant differences between food groups aggregated by EIHD food pyramid in the BMI classes, and Exploratory Factor Analysis did not show acceptable reliability of the factors. So, the conclusion is that in Pärnu database there were no significant differences in consuming different foods by different BMI classes. On the other hand, there was a small correlation between age and BMI, and some differences between educational level and BMI classes. There were also differences between men and women and underweight persons compared to other BMI classes in eating white bread. Men used more salt and especially fine salt, and 51\% of obese respondents used refined sugar, which is approximately $25 \%$ more than respondents from other BMI classes. 50\% of obese and overweight respondents were still satisfied with their physical fitness even if they were less active than normal-weight persons. 


\section{REFERENCES}

1. Costello A.B., Osborne J.W. (2005). Best practices in exploratory factor analysis: Four recommendations for getting the most from your analysis. Pract Assessment, Res Educ, 10, 1-9.

2. Gidding S.S., Lichtenstein A.H., Faith M.S., Karpyn A., Mennella J.A., Popkin B., Rowe J., Van Horn L., Whitsel L. (2009). Implementing American Heart Association pediatric and adult nutrition guidelines. Circulation, 119, 8, 1161-1175.

3. Kim Y., Lee J.-M., Kim J., Dhurandhar E., Soliman G., Wehbi N.K., Canedi J. (2017). Longitudinal associations between body mass index, physical activity, and healthy dietary behaviors in adults: A parallel latent growth curve modeling approach. PLoS One, 12, 3, e0173986.

https://doi.org/10.1371/journal.pone.0173986

4. Lichtenstein A.H., Appel L.J., Brands M., Carnethon M., Daniels S., Franch H.A., Franklin B., Kris-Etherton P., Harris W.S., Howard B., Karanja N., Lefevre M., Rudel L., Sacks F., Van Horn L., Winston M., Wylie-Rosett J. (2006). Diet and lifestyle recommendations revision 2006: A scientific statement from the American Heart Association nutrition committee. Circulation, 114, 1, 82-96.

5. Muñoz-Pareja M., Guallar-Castillón P., Mesas A.E., López-García E., RodríguezArtalejo F. (2013). Obesity-related eating behaviours are associated with higher food energy density and higher consumption of sugary and alcoholic beverages: A cross-sectional study. PLoS One, 8, 10, 1-9.

6. Oda-Montecinos C., Saldaña C., Andrés A. (2013). Eating behaviours are risk factors for the development of overweight. Nutr Res, 33, 10, 796-802.

7. Pentikäinen S., Arvola A., Karhunen L., Pennanen K. (2018). Easy-going, rational, susceptible and struggling eaters: A segmentation study based on eating behaviour tendencies. Appetite, 120, 212-221.

8. Pitsi T. et al. (2017). Eesti toitumis- ja liikumissoovitused 2015. [Estonian nutrition and physical activity recommendations in 2015]. Retrieved from https://intra.tai.ee/images/prints/documents/149019033869_eesti\%20 toitumis-\%20ja\%20liikumissoovitused.pdf

9. Tali M., Lusmägi P., Unt E. (2016). Leisure time physical activity in Estonian population: adherence to physical activity recommendations and relationships with overweight. Arch Public Health, 74, 1, 36. https://doi.org/10.1186/s13690-016-0148-6

10. Tekkel M., Veideman T. (2017). Health behavior among Estonian adult population. Retrieved from

https://intra.tai.ee//images/prints/documents/149069399613_Eesti_taiskasvanud_ rahvastiku_tervisekaitumise_uuring_2016.pdf

11. Thaler A., Geuss M.N., Mölbert S.C., Giel K.E., Streuber S., Romero J., Black M.J., Mohler B.J. (2018). Body size estimation of self and others in females varying in BMI. PLoS One, 13, 2, 1-25. 
12. Tilts I. (2010). Kohaliku omavalitsuse ja maakonna terviseprofili koostamine. [Compilation of the health profile of local government and county]. Retrieved from http://www.tai.ee/et/valjaanded/download/87

13. Victorian Health Promotion Foundation. (2016). Obesity and healthy eating in Australia: Evidence summary. Retrieved from https://www.vichealth.vic. gov.au/-/media/ResourceCentre/PublicationsandResources/healthy-eating/ Obesity-and-healthy-eating-in-Australia-summary.pdf?la=en\&hash=C7FD D57D5BAD4211BD37770EB649AA877F3D0C60

14. Viilmann K., Espenberg K., Humal K., Lina J., Nahkur O., Puolokainen T. (2013). Paikkonna tervisemõjurite uuring. Pärnumaa raport. [Study of factors that influence the health: Pärnumaa report]. Retrieved from https://intra.tai.ee/images/prints/documents/138670106464_Paikkonna_ tervisem6jurite_uuring_2011_P2rnumaa_raport.pdf

15. World Health Organization. (1995). Physical status: the use and interpretation of anthropometry. Report of a WHO Expert Committee. World Health Organ Tech Rep Ser, 854, 1-452.

\section{Address for correspondence:}

Kandela Õun

Pärnu College, University of Tartu

e-mail:kandela.oun@ut.ee

Monika Übner

Pärnu College, University of Tartu

e-mail: monika.ubner@ut.ee 